This is the Author Accepted Manuscript version of:

Jason Mosley \& Elizabeth E. Watson (2016), "Frontier transformations: development visions, spaces and processes in Northern Kenya and Southern Ethiopia", Journal of Eastern African Studies, 10:3, 452-475, DOI: 10.1080/17531055.2016.1266199

Please do not cite this version. Please cite the published version. 


\title{
Frontier transformations: Development visions, spaces and processes in Northern Kenya and Southern Ethiopia
}

Jason Mosley* and Liz Watson

African Studies Centre, Oxford University, UK; Department of Geography, Cambridge

University, $U K$.

(Received 17 November 2016; accepted 24 November 2016)

\begin{abstract}
African approaches to development have shifted, particularly in north-eastern Africa. Donor-driven policies have given way to state-led development 'visions', often with a focus on large-scale infrastructure projects - feeding into and reflecting 'Africa Rising' discourses. In Kenya and Ethiopia, these visions include flagship projects in the geographical frontiers, areas previously viewed as buffer zones, whose people have been historically marginalised. This paper adapts the analytical framework from James Scott's Seeing Like a State in order to compare Kenya's and Ethiopia's state visions, and to understand the risks to the populations intended to benefit from such visions from the unintended (but predictable) consequences such projects have had in the past. Keywords: Kenya Vision 2030, Ethiopia Growth and Transformation Plan, frontier infrastructure, development, LAPSSET
\end{abstract}

\begin{abstract}
In the coming five years there will be a very big irrigation project and related agricultural development in this zone [South Omo, Ethiopia]. I promise you that, even though this area is known as backward in terms of civilization, it will become an example of rapid development. I also want to assure you that the work we have started in this area on infrastructure and social development will continue stronger than ever ... whatever they say or do, [they] can't stop us from the path of development we are taking (Prime Minister Meles Zenawi, Jinka 2011).
\end{abstract}

Nearly fifty years after our Independence, inequality between the north and the rest of Kenya persists.... New mindsets and methods, innovative strategies, and the understanding and support of all Kenyans will be required in order to release the potential of the arid and semi-arid lands and help their people enjoy the promise of Vision 2030 (Vision 2030 Development Strategy for Northern Kenya and other Arid Lands, 2011).

The development landscape has changed in Africa. While there has been much attention in the literature on the changing architecture of international aid, ${ }^{1}$ the increasing role of 'Asian drivers' such as China, ${ }^{2}$ and the rise of public-private partnerships, ${ }^{3}$ this paper focuses on a lesser observed phenomenon: the emergence and significance of large-scale and ambitious development plans formulated and promoted by the states themselves. ${ }^{4}$ The new development blueprints and 'visions' articulate a desire to throw off old aid dependencies and to achieve 'middle income status' in less than two decades. The development proposals are a reflection of, and feed into, discourses of 'frontier economies' and 'Africa Rising', 5 and embody an optimistic sense that this time it is different, that old constraints to development will be overcome. The examples of development employed in these visions are also new, as

\footnotetext{
*Corresponding author: jason.mosley@africa.ox.ac.uk
} 
Malaysia, Singapore, South Korea, China, India, Morocco and the United Arab Emirates are held up as models to be emulated rather than European or North American countries. At the same time, the plans are avowedly modern, with a strong emphasis on the transformational power of technology and infrastructure: it is roads, railways, pipelines, fibre-optic cables, dams, irrigation systems, ports and airports that are set to deliver economic and social development.

In Kenya and Ethiopia, these plans, articulated and promulgated first at the centre, have huge implications for the peoples and landscapes at the margins -- geographical, political, social -- of those states. This is particularly the case for the land on either side of the Kenya-Ethiopia border which has historically been considered a buffer zone between the two states, and important largely for its significance to state security. ${ }^{6}$ The activities of the state here tended to be limited to patrolling and monitoring the border areas, and their pastoralist and agro-pastoralist inhabitants were seen by their states as 'backward', environmentally degrading, prone to inter-ethnic fighting and moving across borders, and if anything themselves a security threat. They were mostly ignored by the state - at least in terms of provision of services - or considered an inconvenience and drain on state resources. ${ }^{7}$

The current new interests in the borderlands continue to have a security dimension, as they are still thought to be the potential source of - or close to areas of - political and violent threat. ${ }^{8}$ In rhetoric at least, however, the development visions also represent a new departure: they articulate a desire no longer just to control and contain these regions but also to transform them. First, through mega infrastructure and technology projects they aim to 'open up' frontier areas, and incorporate them fully into the state as never before. Second, the ambitious development projects are heralded as having capacity to tackle the persistent poverty that has characterised these regions and to challenge historic inequalities. As proclaimed by Kenya's overarching development blueprint, 'Vision 2030' 'it offers a chance to turn history on its head'. ${ }^{9}$ Third, the visions mark a further reversal in approach as these frontier regions were formerly seen as unproductive and of little interest; now they are seen as the site of unexploited resources that could provide the engine of growth for the wider national economy; they are the means through which the middle-income status is to be obtained.

Some of the projects outlined in these policy visions exist only on paper, and there is a great deal of uncertainty about how, where and when they will materialise. Others are 
already taking shape. The papers presented in this special collection explore different aspects of some of these real and projected schemes and their outcomes. Even when there is a great deal of uncertainty about what is happening, the papers show that the prospect of large-scale development projects has already led to widespread impacts: in many cases, 'economies of anticipation ${ }^{\prime 10}$ have emerged in which individuals and groups jostle to position themselves as best they can to benefit from expected new resources or compensation, or to mitigate or avoid their expected impacts.

It is an urgent task to understand these development blueprints and the way their real, expected or rumoured arrival in the region has the potential 'to turn history on its head', and also to rewrite the geographies of these areas and their inhabitants. This introduction and the papers that follow attempt to begin this work by exploring different aspects of these development schemes and the ways in which they impact and are understood on the ground. The introduction sets the scene and broadens out the analysis from the individual studies. It compares the Kenyan and Ethiopian cases, and focuses particularly on LAPSSET -- the Lamu Port-South Sudan-Ethiopia Transport corridor, a 'flagship' component of Kenya's Vision 2030 -- and, in Ethiopia, on the Gilgil Gibe III dam and its associated irrigation projects in the Lower Omo valley, as examples of the processes taking place in the frontier regions. Both projects also feature prominently in the individual papers. The introduction returns to the framework from Scott's (1998) Seeing Like a State, in order to facilitate the comparison and make tentative conclusions about future prospects for these regions.

Together the individual papers in this special collection demonstrate the significance of the local understandings of these state visions. How local people respond to the development policy visions and practices depends significantly on their perceptions of the risks and opportunities that they represent. As discussed above, some of these perceptions depend on expectations and rumours of what might happen in the future. They also depend very much on experiences and understandings of the past: on historic relations to the state, on historic experiences of infrastructure and technology (and how costs and benefits were distributed), and on historic balances of power between different groups. Local cultural registers also strongly influence the ways in which the actions of state bodies are framed and understood.

In the first paper, Buffavand explores the impact of the Gibe III dam in Ethiopia, and the conversion of land to large-scale irrigated agriculture. She presents the experiences and 
understandings of the agro-pastoral Mela who are undergoing villagization and attempts to turn them into out-growers in the new sugar plantations in the Omo Valley. ${ }^{11}$ In the second paper, Kochore explores the impact of the smooth new tarmac road that links Isiolo to Moyale on the Kenya-Ethiopia border, which has been constructed as part of the LAPSSET programme. He shows how, for many, the much-longed-for road has brought a positive sense of economic inclusion and belonging; for others it has brought anxiety and fostered senses of alienation. ${ }^{12}$ In the third, Elliott takes a closer look at Isiolo town, the centre of LAPSSET's road, railway and pipeline network, and the location of one of its planned 'resort cities'. She examines the ways in which expectation of LAPSSET's rewards has fed into a rising local land market. The resulting soaring land prices and competition between different factions in the town, has become increasingly ethnicized. ${ }^{13}$ Old struggles between different groups for resources are being amplified in the new context of development and state restructuring. In the fourth paper, Greiner also examines competition for land at individual, communal and ethnic levels, and how it is being exacerbated by anticipation of revenues from developments in tourism, conservation and geothermal energy. This case from Pokot sets these competitions in the context of broader transformations to space, in which common property is increasingly being replaced with more exclusive forms of landholdings. ${ }^{14}$ In the final paper, Cormack turns to Kinna, in the rural hinterland of Isiolo town. Here NGOs and local communities have drawn on ideas of heritage in order to secure a place in the future nation that is being created by Vision 2030. ${ }^{15}$ These strategies are conceptualised as forms of resistance but may ultimately become part of the same wider transformations to space.

Together the papers demonstrate that these new development visions tend to discursively construct the peripheral areas as empty and unproductive in ways that perpetuate old stereotypes and assumptions. ${ }^{16}$ Such discourses enable the governments to cast themselves as heroes who will make these regions anew, but in so doing they discount the value and contributions already existing in or made by these regions. The papers shed light on the range of responses to the development visions and practices. These range from forms of resistance, including from overt campaigns against the development schemes, to refusal to engage with the schemes, to attempts to set up institutions which will rival and challenge the schemes, to 'hidden transcripts' which challenge the legitimacy of the schemes as a whole by contesting their discursive constructions. In many contexts, there are also examples of appropriation, complicity and compliance with the schemes, as individuals and groups attempt to turn aspects of the schemes to their own advantage, often with consequences for 
others. In practice, in each case, many of these responses are evident at the same time, precluding generalization.

First, in this introduction, these papers are framed by returning to the four-point framework set out by Scott to explain why large-scale development projects often fail. Following a short conceptual discussion, there are four substantive sections. These four sections are slightly different from the four components identified by Scott, but they map onto his categories and extend them in useful ways.

\section{Framing large-scale development plans and visions}

In Seeing Like a State, ${ }^{17}$ Scott developed a framework to explain why many large-scale development plans and projects resulted in high social and environmental costs for the people they were ostensibly designed to help. Nearly 20 years after publication much has changed: development is now more driven by markets, international business, and public-private partnerships, suggesting, as Ferguson asserted, ${ }^{18}$ that Scott's framework cannot simply be applied to a neoliberal age. But while the development projects and practices discussed here may have neoliberal elements, they also exhibit strong continuities with the the 'era of modern development' in the middle of the $20^{\text {th }}$ century, when development was led by newly independent states and characterised by technological optimism and large-scale projects. ${ }^{19}$ The development schemes that Scott reviewed were top-down, state-led, self-confident, and exhibited a muscular high-modernism, which has much in common with Ethiopia's dambuilding and villagization, and the mega development plans of Kenya's Vision 2030.

Scott was expert, Li writes, in 'devis[ing] models about big topics' ${ }^{20}$ As such, his work has been argued to have missed subtleties, complexities and variations, ${ }^{21}$ but the broad schema that he outlined in Seeing Like a State captured something of the workings of the state and has continued to be useful to scholars, albeit in modified form. For example, recent analyses have attempted to de-centre the state as the key actor in shaping processes, and to give more weight to technologies of governance and transnational actors. ${ }^{22}$ While these insights are valuable, in this paper we return to Scott's original formulation. Our aim is not to critique the framework but to use it to structure our analysis and to think with. The framework's focus on the state as the key actor is appropriate given the 'visions' we are examining. In addition, Scott's focus on the significance of the modern aesthetic of his state 
plans resonates strongly with our empirical cases. The four components of Scott's framework included: $:^{23}$

1) An 'administrative ordering of nature and society': the state used cadastral surveys, population registers and land titling programmes to make people and their environments 'legible'. This process involved the simplification and standardization of 'complex, illegible, and local social practices' and the reorganization of space and nature. Scott argued that this simplification and standardization is a necessary precursor to the actions of government and can be used to improve welfare as much as it can to control or exploit. It is when combined with the other three elements outlined below that it is more likely to result in harm than good for those at the receiving ends of these development projects.

2) An attachment to a 'high-modernist ideology' with a particular aesthetic: for Scott, this involved a confidence in the ability to bring about successful transformation, a belief in science and technology, and 'above all, the rational design of social order commensurate with the scientific understanding of natural laws'. Again, this 'musclebound' modernism is not in and of itself a problem but becomes 'lethal' when combined with the other components.

3) An authoritarian state which enabled the visions to be implemented: the ordering of nature and society required significant state power, so that, for example, villages in Tanzania or Ethiopia could be made to resemble the model villages in state handbooks. A strong authoritarian state meant that compliance with the plan was achieved.

4) Relatedly, a 'prostrate civil society' meant that resistance could be quelled, or more likely could not emerge.

In what follows, we use these four elements to examine what is happening in the KenyaEthiopia borderlands, but in an order that is different to that set out by Scott. First, we examine the visions and the nature of their modern aesthetic. This serves as an introduction to the case as well as a point of comparison with the schemes set out by Scott. Second we look behind the visions, and examine what they reveal about Ethiopian and Kenyan state-craft. This sets the scene for the later discussion of whether or not the Kenyan and Ethiopian states can be seen as authoritarian and the consequences of this for an assessment of the processes. Third, we turn to Scott's 'reordering of relations between nature and society', and examine 
the ways the projects transform nature-society relations and land management practices. We also explore how the projects intersect with other transformations taking place in the region, including privatization, the enclosure of common land, and the establishment of conservancies. Fourth, we examine the civil society responses to these processes and the range of different civil society actors involved in shaping the project outcomes. The discussion of civil society facilitates a further discussion of the nature of the state, the extent of its authoritarianism, and a reflection again on the potential outcomes of these processes.

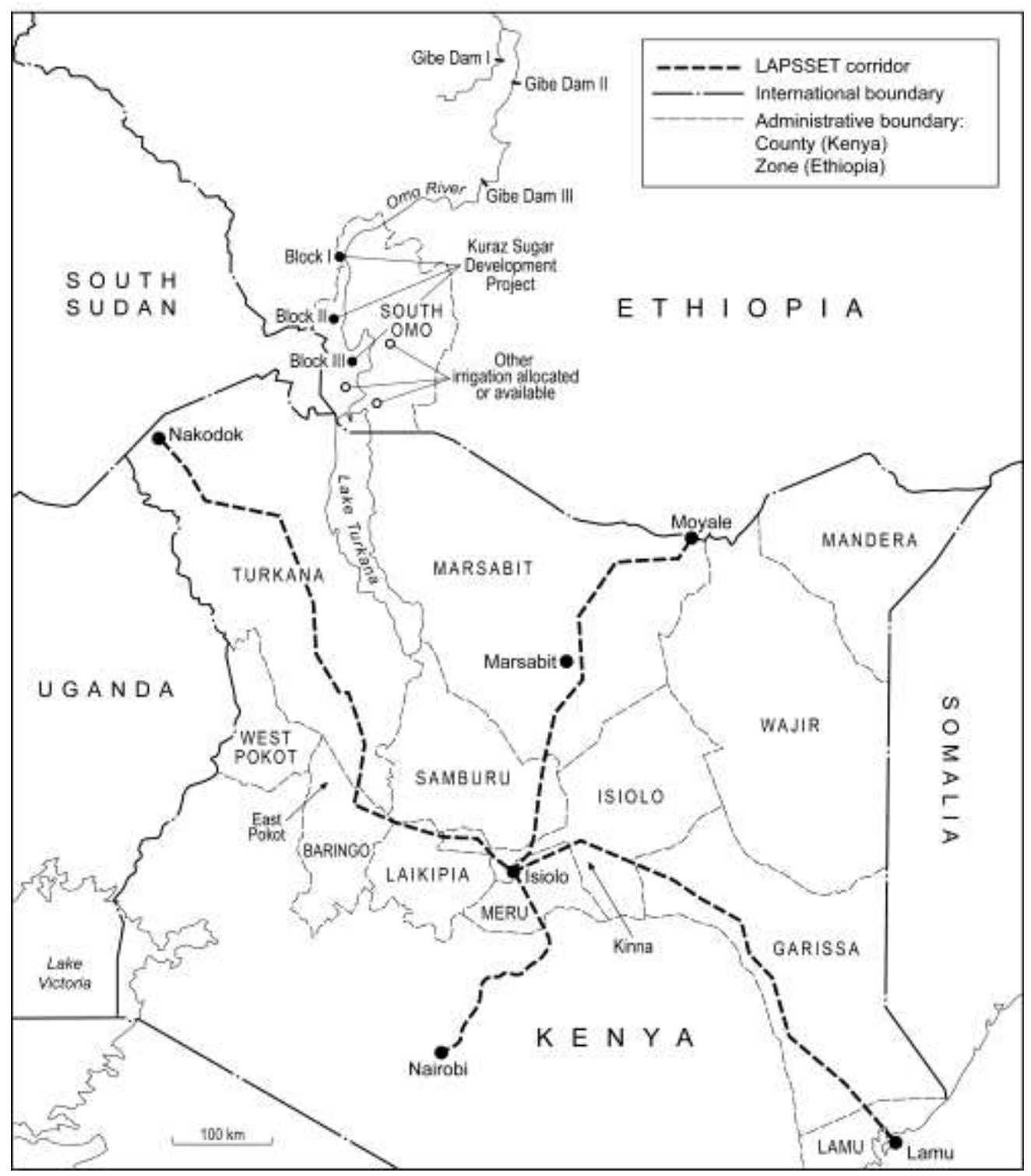

Figure 1: Map of Northern Kenya and Southern Ethiopia showing approximate location of features and places discussed. The LAPSSET corridor includes combinations of railway, highway and/or pipelines along different stretches, and the construction of a port at Lamu. So far, of these elements, the highway from Isiolo to Moyale has been completed (and runs through Marsabit town). Map prepared by P J Stickler of the Department of Geography, Cambridge University drawing on multiple sources. ${ }^{24}$ 


\section{The visions and plans of Kenya and Ethiopia}

Kenya's Vision 2030 was launched in 2006 and started to take effect in the wake of the postelection violence in 2007 through its first five-year plan from 2008-2012. It describes itself as a 'national long-term development blue-print to create a globally competitive and prosperous nation with a high quality of life by 2030 , that aims to transform Kenya into a newly industrializing, middle-income country providing a high quality of life to all its citizens by 2030 in a clean and secure environment'. ${ }^{25}$ It is based on three 'pillars': 'economic, social and political', and on a series of 'flagship' projects and 'enablers and macros' that cross cut the 'pillars' in areas such as infrastructural development, science technology and innovation (STI), public sector reforms and macroeconomic stability. ${ }^{26}$

Kenya Vision 2030 reaches into almost all areas of government and development planning. It has been described as neoliberal in substance, because of its reliance on market deregulation and public-private partnerships, and also in language, because of its 'emphasis on competition, management, performance, and accountability'. ${ }^{27}$ But in many ways, the characteristics of Kenya Vision 2030 also make it more like the 'development decades' of 1960s/1970s, as the state continues to have a strong role in delivering development, and improvements in technology and infrastructure, and the ordering of nature and society, are thought to bring about new modern lives, with, as the quote above indicates, new 'mindsets'.

The ambition of the new vision makes it like Scott's 'high modernist ideology', but this time it is promulgated in attractive new websites and publicity films freely available on the internet and as well as in conventional policy documents. One presentation for its Vision 2030 development blueprint is illustrative ${ }^{28}$ : it describes the country as on a 'transformation journey' away from a situation of, among other things, a 'crumbling road network', and 'inadequate farming methods'. A set of slides entitled 'The Kenya we want' are composed of futuristic pictures of convention and business centres, tourist 'resort cities', and place heavy emphasis on the development of Lamu Port, and its accompanying road, railway and pipeline network, part of Kenya Vision 2030's flagship LAPSSET project. These 'transformation visions' are hyper-modern, like those of Scott, but they are also postcolonial as they take as their models for development 'high growth countries' like Morocco, Malaysia, Singapore, China and India. ${ }^{29}$ The Middle East is also an inspiration: the port development is seen as explicitly able to 'bring Dubai to Kenya' ${ }^{30}$; the conceptualization of Lake Turkana's resort 
city appears to draw much from the aesthetics and ambition of Dubai's palm island developments $^{31}$; and government officials from the arid and semi-arid northern regions have visited Middle Eastern countries for inspiration on how to proceed with development.

These are state visions that place great emphasis on technology and communication networks, but, as well as conventional technologies like irrigation and conventional communication network components like roads, they also emphasise information communication technologies, digital learning and business, and work in partnership with international investors and consultants. Indeed, some accounts suggest the vision was developed in partnership with McKinsey and Company, who have also worked on similar 'visions' elsewhere. As one Kenyan commentator in the Daily Nation newspaper wrote: 'While a national dream is conceived by people, Vision 2030 was not conceived internally by Kenyans but externally by McKinsey \& Company of South Africa that has been conceiving and selling "national visions" to African countries like Kenya. Ours is Vision 2030, Rwanda's Vision 2020, Burundi's Vision 2025, Tanzania's Vision 2025, and so forth', ${ }^{32}$ raising multiple questions about authorship and also pointing to the wider relevance of scrutiny of these visions.

Ethiopia's development plan has been equally ambitious. Its Growth and Transformation Plan (GTP) started with its first five-year phase in 2010, with the aim of maintaining an economic growth rate of $11.2 \%$. Like Kenya Vision 2030, it identified a series of 'pillars', including: rapid and equitable economic growth; agriculture-led economic growth; industrialisation (including higher value-added agro-industry as well as more conventional sectors such as textiles); infrastructure; social development; good governance; and gender and youth empowerment and equity. ${ }^{33}$ The second phase (GTP II) began in 2015, with the aim of achieving middle income status by 2025. In Ethiopia, the visions of development continue a tradition of policies designed at the centre and rolled out to the periphery. There has been strong support for foreign investors, but in practice Ethiopianbased private investors and state bodies remain significant actors in agriculture, industry and infrastructure construction. Development here is cast as a 'renaissance', as the prime minister explained, 'The country was known for destitution, famine, being war-torn and all those kinds of poster-child issues. That history has gone. Now this is a country that is emerging., 34 Infrastructure building - with a focus on roads and hydro-electric dams and electrical transmission infrastructure - has been particularly evident with the aim that Ethiopia will 
become an energy 'powerhouse', exporting energy to its neighbours in coming years. Largescale infrastructure development has often been assumed to be possible because of assistance from new development actors like China. Some of this is true: China has been involved and is currently funding power line construction, as is the World Bank and African Development Bank. But a large part of the dam-building has been facilitated by money from government bonds, including schemes for the diaspora and for public and private employees who are encouraged to buy bonds to fund dam construction. Fourie argues, however, that China also offered a model of development for Ethiopia, with its focus on state interventionism, infrastructure and lack of support for democratic reforms. ${ }^{35}$ Indeed, although the particular focus of the government's economy policy framework has shifted since the Ethiopian People's Revolutionary Democratic Front (EPRDF) took power in $1991,{ }^{36}$ the experiences of East and South East Asia's developmental states (especially China, Taiwan and South Korea) have been key reference points for planning - both in terms of the role of the state and in terms of the approach to managing rent-seeking and guiding private sector participation in the economy. ${ }^{37}$

The Kenyan and Ethiopian visions are very different, but they are equally focused on infrastructure, economic transformation and achievement of middle-income status. Both visions/plans have an aesthetic, more slick in the Kenyan case, but equally reliant on a 'selfconfidence about scientific and technical progress, the expansion of production, the growing satisfaction of human needs [and] the mastery of nature'. ${ }^{38}$ In Ethiopia the borderlands are seen explicitly as areas that are 'backward' and to be civilized by these projects. As Meles explained in relation to the Gilgil Gibe III dam: 'Even though poverty and backwardness is a concern for the whole country, it is worse for the pastoralists'. ${ }^{39}$ In Kenya, the north is constructed as facing multiple challenges because of its history in which 'The defining feature of Northern Kenya is its separation from the rest of the country, which manifests itself in both physical and psychological ways'. ${ }^{40}$ It is also constructed as empty and underutilized, and therefore as having untapped potential, particularly for trade, tourism and energy sectors.

\section{State-craft at the frontier}

Although the infrastructural transformation envisioned by both Kenya's and Ethiopia's governments is similarly grandiose, the nature of the states behind these visions is somewhat different. A tendency towards centralised authority in Ethiopia has been maintained across time, even after federalism was implemented from 1995. In Kenya, a fractured political elite 
has hampered the ability of centralising governments to manage political competition, even under single-party rule until the early 1990s, but particularly since long-standing President Daniel Arap Moi stepped down in 2002. The implementation of a new constitution in 2010, especially the establishment of devolved county administrations since 2013, has accelerated the competing centripetal and centrifugal forces in Kenyan national politics. These trends carry significant implications for populations in the frontier areas, whose relations to the states have been fraught, but who have also in many cases developed livelihoods and political systems well adapted to the limited state presence, and the opportunities presented by the borderlands. ${ }^{41}$

\section{Ethiopia's continuity}

The long history of the Ethiopian state has been shaped by its precarious geographical and political position. Late $19^{\text {th }}$ century political consolidation in Ethiopia (including the imperial regime's southern and western expansions ${ }^{42}$ ) and the state's agreements with European colonial powers produced the recognisable geography of the country, including its peripheries. ${ }^{43}$ During the second half of the $20^{\text {th }}$ century, the imperial (until 1974) and Derg (1974-1991) regimes sought to transform the economy, in large part in order to bolster the resources of the state. Under the Derg, the nationalisation of land and imposition of collectivised agriculture reflected the state's urge to order and manage economic activity, and underscored the connections between economic and national security. When the EPRDF took power in 1991, it faced a quandary familiar for leaders of the Ethiopian state. The Horn of Africa has a history of interstate wars stretching back at least to the $19^{\text {th }}$ century. Indeed, as an armed liberation movement, the EPRDF's leaders had maintained links to neighbouring regimes in Sudan and Somalia during their struggle. In addition to the challenging regional security landscape, Ethiopian leaders have largely presided over an agrarian-dominated economy, mainly focused on subsistence. Efforts under the imperial and Derg era governments to modernize agriculture, in order to increase revenues and exports, achieved little success. ${ }^{44}$ This has begun to change under the EPRDF, and in particular with regard to the government's ability to economically exploit the country's frontier areas. ${ }^{45}$

The country has long run a trade deficit, producing historical balance of payments pressure. Ethiopia has largely been able to relieve the pressure from the current account deficit with bilateral assistance. During the Cold War, Ethiopia's geography (especially is proximity to the Red Sea) enabled it to cultivate relations with first the United States under the imperial government, and then the Soviet Union under the Derg. For the EPRDF, which 
took power as the Cold War order was collapsing, bilaterial aid, mainly from OECD donors, has emerged to fill the gap. Although the strategic salience of Ethiopia's geography has faded somewhat in Cold War terms, its regional security role has re-emerged, as the United States has increasingly defined its engagement in the region in terms of countering terrorism (particularly since 2001, but even in the 1990s). The EPRDF has been able to leverage its strategic alliances in terms of maintaining aid flows, even in the face of criticism of its democratic or human rights records from its donors. ${ }^{46}$ However, in the view of the EPRDF, dependence on foreign aid to help mitigate the balance of payments pressure represents a structural vulnerability. ${ }^{47}$ As such, the government's economic development strategy is focused on protecting Ethiopian national security, as much as it is on job creation and poverty reduction. The belief is that boosting exports by expanding the agro-processing and manufacturing sectors will lead to the accumulation of foreign exchange reserves (and thus a reduction of dependence on donors).

The government's targeting of the peripheries as the site of large-scale agriculture enterprises marries both its national and economic security priorities with the long-standing dynamics of Ethiopian state attempts to control and exploit the frontier. The past decade in particular has marked a marked shift in status for these regions, from 'buffer zones' of limited engagement to more actively exploited economic areas. ${ }^{48}$ The Lower Omo joins other such areas - including Gambella, the western border areas of Beni-Shangul Gumuz (the location of the 6,000MW Grand Ethiopian Renaissance Dam under construction on the Blue Nile) and the Ogaden - in being more tightly linked to government economic and political planning. Although the form of Ethiopia's state changed considerably during the second half of the $20^{\text {th }}$ century (from monarchy to military dictatorship to ethnic federalism), in practice the pressures of managing a diverse population and countering external security pressures has seen successive governments maintain a centralised, authoritarian approach to policy and planning (as well as politics). ${ }^{49}$

The government presence in the Lower Omo under the imperial and Derg governments was limited to small military deployments, local administration with limited resources and the declaration of the Omo and Mago national parks - reflecting the limited capacity of the state to project its interests into its frontiers, or effectively exploit the resources of these areas. ${ }^{50}$ In the last decade under the EPRDF, the Gilgil Gibe series of hydroelectric dams -- particularly the 1,870MW Gilgil Gibe III dam and an associated scheme of irrigation-fed plantation projects in the Lower Omo -- represent a shift in this pattern. The electricity generated will (for the time being) allow Ethiopia to create a surplus. 
A 1.3 billion dollar, World Bank and African Development Bank financed transmission line will enable electricity exports to Kenya, helping to reduce the trade deficit. Moreover, GTP and GTP II have targeted massive increases in agricultural commodity exports, with sugar processing and export intended to boost hard currency earnings. The Kuraz Sugar

Development Project, run by the state-owned Ethiopian Sugar Corporation and irrigated from the Omo River, is intended to cultivate 175,000ha of sugar cane, although as of mid-2016 only about 13,000ha had been cleared, and 10,000ha of sugar cane had been planted, with three processing factories still under construction. ${ }^{51}$

\section{Kenya's shifting frontier}

The attention of Kenya's governing elites has only shifted to the economic potential of its northern regions relatively recently. For most of the history of Kenya, colonial and postcolonial, Northern Kenya was viewed from Nairobi as a marginally productive zone, maintained as more of a buffer between the rest of Kenya and the restive Somali inhabited regions than as an actively managed region. ${ }^{52}$ Around the period of independence, Northern Kenya itself became a zone of conflict and insecurity, with a state of emergency in place until the early 1990s. ${ }^{53}$ Although the vision of a major port at Lamu was first mooted by colonial administrators, an idea revived in the 1970s, it was only moved towards implementation under Vision 2030 during the past decade, as part of the LAPSSET agenda. At its core, LAPSSET includes a new, modern deepwater port at Lamu, connected by a new highway to the main Kenya economic centres as well as to the Ethiopian and South Sudanese borders. The broader agenda includes a new railway along the same route, as well as a pipeline (whether for shipment of refined petroleum products from Lamu inland, or for export of crude oil from Uganda, South Sudan and Kenya), as well as new airports and resort cities at key nodes of the corridor (in Lamu, Isiolo and Turkana). ${ }^{54}$

Vision 2030, developed under the administration of President Mwai Kibaki (200213), reflects in part an increase in planning capacity and developmental vision, as well as in the reach of the state and the resources at its disposal. Military spending has doubled since $2000,{ }^{55}$ while the Kenya Revenue Authority has overseen average annual increases of more than $15 \%$ in revenue collected during the decade to $2013 .{ }^{56}$ More dramatically at the local level, the devolved system of county government created under the 2010 constitution and implemented following the 2013 elections has seen the establishment of important new bureaucracy at a local level across the country. These new administrations are responsible for 
spending a significant proportion of government funds (although the capacity of those new administrations appears to vary widely). ${ }^{57}$

These factors have enabled the expansion of the state-building/state-consolidation process into previously marginalized parts of the country. From the view of planners in the central government, the motivation for doing so is related strongly to the economic potential of these regions. This applies to Lamu County and Northern Kenya, in terms of the location of the new port (a key strategic economic asset for Kenya), as well (potentially) as oil and gas resources. The creation of the county governments has complicated this process, by adding an additional level of bureaucracy and additional opportunities for political patronage; this both reinforces the overall state-building agenda (given the continued influence of the central government at the county level, formally and informally) and introduces new mechanisms for local stakeholders (particularly local political elites) to pursue regionally defined agendas within the framework of state structures. ${ }^{58}$

The salience of LAPSSET for the centralised economic vision - and thus the shift from buffer zone to important economic asset -- has been underscored by Kenya's military intervention in Somalia. When a string of kidnappings in Lamu and northern Kenya took place in mid-2011 - blamed on criminality and insecurity spilling over from Somalia - it triggered a Kenyan security intervention in Somalia to protect the LAPSSET agenda in northern Kenya and Lamu (Operation 'Linda Nchi', or 'protect the country' in October 2011). ${ }^{59}$ Subsequently, Kenya became more (not less) tightly tied into Somalia's security troubles. Al-Shabaab was not displaced from its main base in Kismayo until September 2012, but the Kenyan intervention had already triggered an escalation of al-Shabaab's activities inside Kenya, directly and by supporting local, sympathetic groups. While the economic imperative and national political concerns may have originally driven the promotion of LAPSSET, it now represents a project that is valued because the improved communications its roads and developments would bring are also part of a regional security agenda.

\section{Transformations to space}

At the same time, the development visions and projects are part of a set of processes which are reordering the relations between nature and society. The visions, plans, new developments and investment activities are bringing with them new spatial patterns and new forms of human-environment relations. It is tempting to see these processes as a reflection of 
the wider trend of large-scale land acquisitions and land grabs; 'a new scramble for Africa'. As Abbink wrote:

One could speak of a 'new scramble for Africa' - a rush by rich countries to get as much land as possible and not 'stay behind', motivated by the wish to secure future food supply sources. The term 'scramble' finds additional justification when we see the haste, the lack of negotiation about conditions, the privileging of foreigners over locals... ${ }^{60}$

A 'scramble' is taking place but it is somewhat different to that which is often assumed: the wider land grabs literature often focuses on transnational companies leasing land for commercial food or biofuel production. Here the 'scramble' equally involves enclosure and an anxiousness to have a 'stake' before it is all taken by others, but there is a wider set of actors including transnational corporations, states, individuals, NGOs and conservation organizations, all of which are negotiating with each other over access to and use of land. Sometimes the different actors are operating in alliance; at other times they are enclosing land in order to resist what is perceived as the threat of enclosure from others. The result is the emergence of a new mosaic of enclosed territories, where each territory has its designated use and user; other uses are prohibited and other users excluded.

In the Omo Valley, the government has advertised land to foreign investors at attractive rates, with very reduced rates of taxation for companies willing to go to the 'remote' areas of the Omo Valley. But so far, the involvement of foreign companies has been dwarfed by that of the state, with the state-owned Ethiopian Sugar Corporation remaining the largest actor. ${ }^{61}$ The pastoralists and agro-pastoralists who formerly practised flood retreat irrigation using waters from the Omo River are to become outgrowers and/or to be moved into new planned villages. Existing experiences of outgrowers in other state-owned sugar plantations in Ethiopia do not bode well for the former agro-pastoralists: Lavers describes how as part of outgrowing scheme for sugar in East Shewa, smallholders who formerly had choice over what they grew and what they did with it, became wage labourers in cooperatives with little choice but to accept conditions and low payments. ${ }^{62}$ Reports from the new planned villages in the Omo Valley tell of lives characterised by insecurity, poverty and loss of cultural sites and meaning. ${ }^{63}$

The role of transnational companies in the region should not be underestimated, however. Oil companies are active in northern Kenya and southern Ethiopia. In northern Kenya, foreign companies have also been involved in setting up new wind and geothermal power development, including the Lake Turkana Wind Power Project (LTWP), set to be the 
largest wind project in Africa. ${ }^{64}$ The area to be affected by the wind farm is estimated at 40,000 acres, and it is also accompanied by a new $200 \mathrm{~km}$ road project. According to some reports, 'there are no land tenure issues for the nomadic communities as LTWP has accepted the cultural 'right of use' tenure for grazing livestock and traversing LTWP's land'. ${ }^{65}$ But the allocation of land to the private investor has been contested and the LTWP has been accused of partiality in its engagement with ethnic groups in the region, employing 'divide-and-rule tactics'. ${ }^{66}$ The situation is complex, but illustrates that customary rights have hitherto been poorly protected. The situation is possibly set to change, as in August 2016 a Community Land Act was finally signed into law, 'to provide for the recognition, protection and registration of community land rights' ${ }^{67}$. However, many questions remain about how, when and where this Act will be put into practice.

The role of foreign investors in the increasing enclosure of land is easier to see in the case of oil. Although the territories allocated to oil exploration are smaller by comparison, they are highly fortified. Enns has described how oil companies employed Kenya Police Reserves (KPR) and local youths through arrangements with central and County governments to protect their installations:

They help secure oil wells and other infrastructure, such as private company airstrips. They also provide protection to company personnel during exploration activities. Unarmed youth are hired to monitor the roads that oil companies have constructed to reach their wells. This role includes waving down and redirecting vehicles that are not licensed to the oil companies, as well as pastoralists who wander too close to wells in search of greener pastures. ${ }^{68}$

The situation resembles the 'enclave development' that Ferguson argues has characterised oil exploration in Africa in the neoliberal period. ${ }^{69}$ Here territorial enclaves are set apart from their surrounding areas 'often literally walled, with bricks and razor wire' ${ }^{70}$, and protected by private security services. Capital does not flow across territories to these enclaves, it 'hops' from one discrete point to another. ${ }^{71}$ This spatial form, Ferguson argues, is in marked contrast to the spatial arrangements that characterised Scott's state-led development with its standardized legible grid.

But there are signs that these enclaves are changing. The oil companies of Tullow Oil and Africa Oil have, from October 2015, set up a five-year partnership with Northern Rangelands Trust (NRT) to manage six new 'community conservancies' in the regions in which they are operating. ${ }^{72}$ NRT is the largest and most experienced community conservation organization in this region. Its community conservancies involve the designation of areas of 
land to be managed by communities with the aim of generating income from opportunities such as tourism, carbon sequestration or livestock trading. NRT is thus a conduit for the oil companies to contribute to the development of their neighbouring communities, in part so that they have 'informed and positive support from local communities' and a 'social license to operate'. ${ }^{73}$ But partnership with NRT is also a means through which the oil companies can secure the wider area and mitigate against potential threats to their activities. As NRT summarizes: 'Development and maintenance of a safe, secure, peaceful and stable working environment for oil operations with informed and positive support from local communities' ${ }^{74}$ NRT employs militarized rangers that patrol their conservancy territories to 'secure peace', countering the threats from poachers (who can be very sophisticated and organized), from cattle raiding, or from any other kind of violent attack. Through partnership with NRT, it seems the oil companies hope to ensure that the northern regions in which they work are made legible and secure.

The NRT conservancies are relatively new (since 2004), but are by far the most extensive conservation projects in this dryland region. They must be seen in the context of the wider history of conservation in Africa. ${ }^{75}$ Earlier forms of 'fortress conservation', in which people were largely excluded from protected areas, have, in the late $20^{\text {th }}$ and early $21^{\text {st }}$ centuries, given way to more community-based approaches. ${ }^{76}$ But while community conservancies (forms of community-based conservation) may not exclude people from conservation areas altogether, they still bring with them new forms of territoriality which link people more closely to particular bounded areas for the purposes of better resource management and revenue sharing. The name 'community conservancy' belies the complexity of defining the 'community' associated with a particular area. This is particularly the case in this region as the pastoralist inhabitants have historically moved with their animals to find water, or from dry season to wet season grazing areas, and in response to weather events. The establishment of community conservancies raises questions which often go unanswered about how to manage movement across conservancy borders. Most significantly, those who are not considered to be part of the recognized 'community' may experience reduced access and exclusion. ${ }^{77}$

Elsewhere in the north of Kenya, conservancies have been formed in opposition to the perceived threats by the mega-developments and there they have also taken a more exclusive form. An example is the Amu Ranch conservancy in Lamu County, taking up approximately 
63,000 acres on the mainland, in the middle of an area now central to the LAPSSET infrastructure plans (a new airport slated to be built would occupy a portion of the conservancy). The process of establishing the ranch involved seemingly contradictory incentives, and reveal layers of local political elites, as figures marginalized by some of the county's broader political dynamics in turn themselves marginalized smaller groups in order to control the resources the ranch represented. At the same time, those in control of the ranch are also allied with other groups in seeking to minimize risks from LAPSSET and to maximize any opportunities the mega-project creates. Amu Ranch was established as a cooperative in the 1970s, although its management was never strong, and it is reported that resources on the land were exploited for profit by local politicians (e.g. tropical hardwood). Around 2005, a small group of local political figures, including Arab and Bajuni 'Swahili' individuals, allied with a prominent Coastal (Arab) businessman, Tahir Sheikh Said (known as TSS), to acquire control of the ranch's title and arrange shareholder approval of its conversion to a conservancy. In political and economic terms, the move offered some Bajuni - who are broadly recognized as 'local' but feel marginalized by Arab and other 'outside' political elites - a leading role in controlling a large portion of land in the county. Moreover, as the scope of the LAPSSET agenda in Lamu has become clearer from 2006, the Ranch has provided the means to push back against a Nairobi-led process, with demands for more local influence and control. In 2009, some of the leaders of the Amu Ranch came into contact with the South African NGO Natural Justice, which came to Lamu to work with a coalition of NGOs and CBOs under the name of 'Save Lamu' on developing a 'bio-cultural community protocol' ${ }^{78}$ Since 2009, Save Lamu has evolved from a loose alliance to more of a CBO in its own right. Simultaneously, the leaders of the Amu Ranch moved to consolidate their project. Amu Ranch leaders formally linked with David Sheldrick Wildlife Trust in 2011, under the Lamu Conservation Trust, and conservancy work began in earnest. While empowering some elements of the local elite (certain Banjuni and Arab figures), the Amu Ranch project has also disadvantaged other groups also considered marginalized by the dominant trends in county politics and business. ${ }^{79}$ Small groups, especially Sanye, have subsequently been displaced from ranch land, losing access to water and other important resources (particularly beehives). Amu Ranch has been the target of a legal/political campaign by individuals who claims the ranch includes lands from which they were displaced in the $1960 \mathrm{~s} .{ }^{80}$ The ranch was attacked in July 2014 during the period of wider violence in the county. ${ }^{81}$ 
These enclosures of land have been carried out by formal organizations, state and non-state. Korf et al. remind us that the enclosures are also connected to forms of territorialization, sedentarization and commodification driven by individuals, especially indigenous elites. ${ }^{82}$ This is the story told by Elliott. ${ }^{83}$ In Isiolo, at the centre of the new LAPSSET transport and pipeline network, land is being enclosed in plots and its value is soaring as individuals anticipate the new opportunities that the developments will bring. The state is also increasing its provision of formal titles to land in the town, but it is the individuals and groups that are employing various methods to ensure their rights to the newly privatized land. Greiner ${ }^{84}$ also demonstrates how increasing enclosure of common land is happening at individual, community and ethnic levels. He demonstrates how communities are competing to be associated with particular territories in order that they may benefit from compensation or revenue sharing from new activities like geothermal power or conservancies. At the same time, other groups are resisting these claims, as they fear that - if such claims are accepted - they will be excluded as a result.

Finally, NGOs of different kinds are also playing a part in these new enclosures in the context of these development visions. As Cormack explores, ${ }^{85}$ a Kenyan NGO has drawn on indigenous institutions for managing land and resources in order to resist the threat they perceive is posed by LAPSSET and its accompanying developments. The dedha council was historically a Borana institution that was loosely responsible for grazing activities around a certain settlement or water point. It fell into disuse in the 1990s, and in any case, is not thought to have formerly represented a spatial category; indeed, others have explored how the pastoralist groups in this region did not have emic words for borders, or divide their land up according to particular territories. ${ }^{86}$ In the context of the threat from LAPSSET, the revival of the dedha institution has had a particular spatial dimension, coming to be seen as a means to administer and defend territory. Rather than challenging the increasing ethnic territorialisation in the region, this process - on what is now a highly competitive Meru/Isiolo border - also potentially has the unintended consequences of exacerbating it. As in most of the other cases, ostensibly more localized processes are interwoven with competition between counties in post-devolution Kenya.

The picture that emerges of these marginal areas is of multiple actions by multiple actors increasingly rolling out the standardized, homogenous ' $g r i d$ '. ${ }^{87}$ Territories become associated more exclusively with particular individuals, organizations or groups. Others have 
no place on this grid. The imaginaries of territorial control that accompany these projects are strong, but a closer look at the processes on the ground, as evident in many of the examples in this special collection, shows that the grid, its boundaries, and the control of the bounded areas by specific individuals, groups or institutions, is often contested.

\section{Civil society and contestation}

In Scott's Seeing Like a State, the fourth component of his large-scale schemes that meant that they resulted in 'a mortal threat to human well-being ${ }^{88}$ was a 'prostrate civil society'. In this section we examine the responses of civil society to the different schemes, outlining the different actors and the nature and success of their contestation. Scott was not explicit about who or what exactly he was referring to with the term 'civil society'. It has tended to be equated with NGOs and grass-roots organizations and other 'arena[s] of associational culture or associational groupings' outside the state ${ }^{89}$ Such an approach prioritizes more collective or formal groupings of actors, however, and here we discuss actors of different levels of organization and formality and the ways in which they 'modify, subvert, block and even overturn' ${ }^{90}$ aspects of these schemes. At the same time, it is kept in mind that the degree of organization may make a difference to the extent to which the state plans are implemented and to the extent to which that civil society is considered 'prostrate' or not. The term contestation is also employed rather than resistance, as resistance tends to imply a binary set of power relations (dominant/dominated) ${ }^{91}$ whereas contestation includes the multiple ways in which different actors, relationally situated, oppose, critique or resist the schemes, overtly or covertly, and also the ways in which they challenge the schemes by appropriating and transforming aspects of them in different ways.

First there has been formal and organized resistance to aspects of these large-scale developments in Kenya and Ethiopia. In Kenya, campaigning organizations have formed in direct response to the threats posed by large-scale developments, for example, Save Lamu ${ }^{92}$, Friends of Lake Turkana, ${ }^{93}$ and the Sarima Indigenous Peoples' Land Forum (Defending Our Community Land from Colonial Takeover by Lake Turkana Wind Power Ltd.). ${ }^{94}$ These organizations have fought various aspects of the mega-development plans, through the High Courts, or through the development of legal instruments such as bio-cultural community protocols. ${ }^{95}$ A detailed comparison of these organizations is still awaited, but research so far suggests that these organizations have become more pragmatic, broader in their concerns, and more focused on procedure over time. Instead of universally rejecting the projects, they argue 
for issues like improved environmental impact or social impact assessments, free and fair consent to be obtained from local communities, for recognition of the rights of communities to land on which projects are built, for compensation and/or revenue sharing agreements with local communities. These organizations have also seen themselves as engaged in awareness raising activities, collating data, and challenging wider social and environmental injustices, rather than focusing on these projects in isolation. It is too early to be able to assess their effectiveness and though they appear close to their communities, they have had difficulties of representing diverse affected communities. They are, however, internationally recognized campaign groups, with access to global networks of support.

Other forms of resistance to projects have been more ad hoc. Overt protests by local communities halted oil explorations in Turkana in 2013. Demonstrations of 'hundreds' of people from local communities, called for more jobs for local people, for decision-making to be shifted from Nairobi to Turkana and for more benefits to the region. To extent some these protests were successful in that they achieved some concessions from the oil companies. ${ }^{96}$ As above, the pattern of protests is not one of resistance to the projects necessarily, but of attempting to ensure a greater share of their activities, or to direct them in particular ways.

NGOs, the archetypal form of civil society, have also been involved in contesting what they see as threats to culture and livelihood brought about by Kenya 2030 and LAPSSET. Cormack's case fits this category ${ }^{97}$, but, as suggested above, the NGO in question is struggling not to define legitimate access to and use of land on the basis of inherently exclusionary cultural or historical claims. Her case illustrates clearly, Hall et al.'s comment that 'exclusion has a double edge: every counter to one discourse of exclusion necessarily proposes exclusion on other grounds' ${ }^{98}$

Other forms of contestation include the removal of beacons placed by surveyors mapping the route of the LAPSSET corridor, ${ }^{99}$ and communities have also started demarcating their own plots and allocating titles, without waiting for the formal process or in fear that formal processes might allocate rights elsewhere. The landscape of titling that has resulted is far from the simplified and standardized grid envisaged by Scott or Blomley. ${ }^{100}$ Even cattle raids and ongoing conflicts have been interpreted by some as forms of jostling to gain a share of the resources about to be harnessed in this new economy and to have a share of the 'territorial pie' before it is all taken by others. As Greiner ${ }^{101}$ explains, there is as much compliance with these processes, as much as resistance. The combination of these responses means that the outcome of these visions is unlikely to follow script.

In Kenya, civil society is active; even in these formerly remote areas, social media 
discussions about government activities and corruption is vibrant. The same cannot be said for Ethiopia, where the opportunities to resist mega-developments in democratic spaces (real or virtual) are much more limited. It is possible to conclude that, when comparing the Kenyan and Ethiopian examples, the Ethiopian state resembles more Scott's authoritarian state and 'prostate civil society'. As we have been writing this paper, a wave of protests across Ethiopia has cast some doubt on this conclusion, and time will tell if the situation is changing. But by November 2016, the strong state clampdown on these protests and the establishment of a state of emergency suggest that, so far at least, the conclusion still stands. Hidden transcripts, as outlined by Buffavand, ${ }^{102}$ remain important forms of resistance.

\section{Conclusion}

The state visions and development plans in Kenya and Ethiopia aim to bring profound transformations to regions at the margins of these states. Examining them through the fourpoint framework of Scott suggests that, if their associated development activities are likely to 'fail', in terms of causing social and environmental harm, then the activities in Ethiopia are more likely to fail, than those in Kenya. In Ethiopia, there is the administrative ordering of nature and society, a belief in a muscle-bound high modernism, an authoritarian state and a civil society that, while not prostrate (at least not closer to the geographical centre), has not yet proved able to deter the state-led developmental agenda. The dams and irrigation projects may not deliver on their own promises for the same reasons that their predecessors in Africa failed, ${ }^{103}$ and the outcome may be additional untold harm for the affected communities and their environments. In Kenya, the situation is more complex. There we have the administrative ordering of nature and society and high modernism, but the state is less effective, less authoritarian, and civil society is much less 'prostrate'. In Kenya, there are already questions about the extent to which different elements of these visions will be actualized, and multiple ways that groups and individuals are appropriating, anticipating and shaping the activities with outcomes that are far from those intended. The emergent processes are creating new winners and new losers, but looking at the visions through Scott's lens, it is possible to conclude that the outcomes are likely to be less profound, less far reaching, and less harmful, as a result of these processes of contestation and negotiation.

If we look more carefully at the different semantics involved in our two case studies, these findings should not surprise. A 'plan' and a 'vision' are not the same. Ethiopia has a 'plan' (GTP and GTP II), which is defined as an 'organized (and usually detailed) proposal 
according to which something is to be done; a scheme of action'. ${ }^{104}$ By comparison, a 'vision' has multiple meanings, including from the 'action of seeing' to '[s]omething which is apparently seen otherwise than by ordinary sight; esp. an appearance of a prophetic or mystical character, or having the nature of a revelation, supernaturally presented to the mind either in sleep or in an abnormal state' ${ }^{105}$ Both plans and visions are enacted, but in being performed there is more room in the vision for the agency of the audience that receives and interprets it. The outcomes are therefore less controllable or predictable. Audiences are important to both visions and plans at different levels, however. On the international development stage, they may be a means to lever funds and other resources, and the role of visions and plans at this scale is a subject for further research. They both play to national audiences and we have seen how they play an important role in nation building. But most of all, our paper has focused on the relationship of these visions and plans of state to their audiences in the marginal regions that are thought to be their beneficiaries as well as their engines of growth, the means through which the wider objectives can be achieved. The analysis demonstrates the rich variety of interpretations and responses of these audiences that depend on history, culture, emic visions of the future and different opportunities that arise. This variety is often overlooked in development scholarship but the powerful impact that it has on shaping outcomes reveals that it is deserving of much further attention.

\section{Acknowledgements}

The authors would like to thank the contributors for their participation in the various events which have shaped the collection, as well as the British Institute in Eastern Africa for its support; the collection is linked to its 'Bio-cultural frontiers' research theme. Christopher Clapham and Michael Jennings provided helpful feedback on the collection at an early stage. Jason is grateful to Daniel Branch, Ngala Chome, and Jeremy Lind for influencing his thinking on these themes over the past five years, and acknowledges DDG Kenya for supporting fieldwork in Lamu County in 2015. Liz acknowledges the support of the Leverhulme Trust for fieldwork which influenced this paper.

\section{Endnotes}


${ }^{1}$ Dodds, 'The Third World'; Mawdsley, 'Development geography'.

${ }^{2}$ For example, Carmody, 'An Asian-driven economic recovery'; Mohan, 'Beyond the enclave'.

${ }^{3}$ Mawdsley 'DFID, the private sector'.

${ }^{4}$ For an exception see Power, 'Angola 2025'.

${ }^{5}$ See for example, Christine Lagarde's speech at IMF conference, 2014,

http://www.imf.org/external/np/speeches/2014/052914.htm, accessed, November 22, 2016.

${ }^{6}$ Barber, Imperial Frontier; Reid, Frontiers of Violence. Donham and James, The Southern Marches; James et

al. Remapping Ethiopia; Schlee and Watson, Changing Identifications.

${ }^{7}$ Catley et al. Pastoralism and Development.

${ }^{8}$ Menkhaus 'Conflict Assessment'; Okumu, 'Resources and border disputes'.

${ }^{9}$ Government of Kenya 'Vision 2030: Development Strategy', 8.

${ }^{10}$ Cross, Dream Zones; Elliott this volume.

${ }^{11}$ Buffavand, "The land".

${ }^{12}$ Kochore, "The road".

${ }^{13}$ Elliot, "Planning".

${ }^{14}$ Greiner, "Land-use change".

${ }^{15}$ Cormack, "Pastoralist heritage".

${ }^{16}$ See also Makki, "Development by dispossession".

${ }^{17}$ Scott, Seeing Like a State.

${ }^{18}$ Ferguson, "Seeing like an Oil Company".

${ }^{19}$ Gilman, Mandarins of the Future.

${ }^{20} \mathrm{Li}$, "Beyond "the state", 383.

${ }^{21}$ Mitchell, Rule of Experts.

22 Bridge, "Resource Geographies" for review.

${ }^{23}$ The following framework is drawn from Scott, Seeing Like a State, 2-5.

${ }^{24}$ Including Avery, Impacts of hydropower.

${ }^{25} \mathrm{http}: / /$ www.vision2030.go.ke/index.php/vision/ (accessed 23 February 2016).

${ }^{26} \mathrm{http}: / /$ eastafricanchamber.org/attachments/article/64/Kenya\%20Vision\%202030.pdf (accessed 23 February 2016).

${ }^{27}$ Linehan, "Reordering the Urban Archipelago", 25.

${ }^{28}$ See https://www.youtube.com/watch?v=xRJ9S9rKKcQ (accessed, 11 January, 2016).

${ }^{29} \mathrm{http} / / /$ eastafricanchamber.org/attachments/article/64/Kenya\%20Vision\%202030.pdf (accessed 23 February 2016).

${ }^{30}$ http://www.vision2030.go.ke/wp-content/uploads/2015/06/Popular_Version1.pdf; see also Kochore, "The road"; and for comparison Power 'Angola 2025'.

${ }^{31}$ See for example, https://www.youtube.com/watch?v=0BXGh0EYJtE (accessed 3 March 2016).

${ }^{32}$ Koigi wa Wamware, 'As a taxpayer, I need to know: What is this Vision 2030 and who owns it?', Daily

Nation, 19/7/11 http://www.nation.co.ke/oped/Opinion/What-is-this-Vision-2030-and-who-owns-it/4408081204068-nq36xr/index.html, (accessed 17 November, 2016).

${ }^{33}$ FDRE, The Second Growth and Transformation Plan. Electronic copy in author's possession.

${ }^{34} \mathrm{http} / / / \mathrm{www}$.france24.com/en/20150502-down-earth-ethiopia-green-renaissance-dam-climate-railwayenvironment, (accessed 11 January 2016)

${ }^{35}$ Fourie,"China's example".

${ }^{36}$ Lefort, "The Ethiopian Economy".

${ }^{37}$ Vaughan, "Revolutionary state-building", 623; see also, Bach, "Abyotawi democracy", 650-651.

${ }^{38}$ Scott, Seeing Like a State, 4.

${ }^{39}$ Cited in Fratkin "Ethiopia's Pastoralist Policies".

${ }^{40}$ Government of Kenya, "Vision 2030 Development Strategy", 12.

${ }^{41}$ Dereje and Hoehe, Borders and borderlands. Catley et al, Pastoralism and Development.

${ }^{42}$ Donham and James, Southern Marches.

${ }^{43}$ Reid, Frontiers of violence.

${ }^{44}$ Eshetu, Underdevelopment in Ethiopia.

45 James et al, Remapping Ethiopia.

${ }^{46}$ Dereje, 'Aid negotiation'.

${ }^{47}$ Mosley, "Peace, bread and land", 12; See also Daniel Branch and Jason Mosley, "Why East Africa's Borders Are Blowing Up", Democracy Lab, Foreign Policy, August 2014

(http://www.foreignpolicy.com/articles/2014/08/06/why_east_africas_borders_are_blowing_up).

${ }^{48}$ Markakis, Last Two Frontiers. 
${ }^{49}$ Vaughan, 'Revolutionary state-building'. See also, Clapham, Transformation and Continuity, and Markakis, Last Two Frontiers.

50 Turton, 'Wilderness, wasteland or home?'

${ }^{51}$ Kamski, "Kuraz Sugar Development Project".

52 Oba, Shadows of Empires.

${ }^{53}$ Whittaker, Insurgency and Counterinsurgency.

${ }^{54}$ Browne, "LAPSSET".

55 Branch and Mosley, "East Africa's Borders".

${ }^{56}$ Kenya Revenue Authority, "Fourth Quarter and July-June Revenue Report 2013-14", July 15, 2014 (http://www.kra.go.ke/notices/pdf2014/Revenue\%20Performance\%20Report\%202013\%20-\%2014\%20FY.pdf).

57 Otieno, "Devolution and peace"; see also Kimenyi, "Devolution and Resource Sharing".

58 Chome, "Devolution for development".

${ }^{59}$ For a concise summary of the motivations behind the Kenyan intervention, see Anderson and McKnight,

"Kenya at war". See also Branch and Mosley, "East Africa’s Borders"; Totolo, "Kenya's 'Economic' Conflict"; Think Security Press, "National Security Profile”, especially pp 57-60; Kabukuru, "Why Kenya Is Fighting”; and Rosen, "Strategic Posture Review". See also, Anderson, "Why Mpeketoni matters".

${ }^{60}$ Abbink, "Land to the Foreigners", 514-5.

${ }^{61}$ Kamski, "Kuraz Sugar Development Project".

${ }^{62}$ Lavers, "Patterns of agrarian transformation".

${ }^{63}$ Buffavand, "The land"; see also, Tewolde and Fana, "Implications of Sugar Development", and Asnake and Fana, "Expansion of the Sugar Industry".

${ }^{64}$ Enns "The Master's Tools".

${ }^{65}$ Full Resettlement Action Plan Summary. http://www.afdb.org/fileadmin/uploads/afdb/Documents/Projectand-Operations/RAP_summary_Sirima_Village_Lake_Turkana_Wind_Power_Project.pdf (accessed 22

November 2016).

${ }^{66}$ http://siplf.org/en/Background/ (accessed 2 March 2016).

${ }^{67}$ Government of Kenya, Community Land Act, 2016.

${ }^{68}$ Enns, "The Master's Tools", 12.

${ }^{69}$ Ferguson, "Seeing like an oil company".

${ }^{70}$ Ferguson, "Seeing like an oil company", 379.

${ }^{71}$ Ibid.

72 http://www.nrt-kenya.org/nrtandtullow/ (accessed 1 March 2016).

73 http://www.nrt-kenya.org/nrfaqs/ (accessed 1 March 2016).

${ }^{74}$ Ibid.

75 Adams, Against extinction

76 Hutton et al. "Back to barriers".

${ }^{77}$ Greiner, "Unexpected consequences".

${ }^{78}$ See Save Lamu website: http://www.savelamu.org/about-us/ (Accessed 25 October 2016)

${ }^{79}$ Interview with Sanye villager, near Amu Ranch, 27 February 2015; Interview with CBO activist, Lamu

Town, 28 February 2015; Interview with CBO leader, Lamu Town, 2 March 2015.

${ }^{80}$ See Cheti Praxides, 6000 "Lamu squatters want their land back", The Star, March 6, 2014 (http://www.thestar.co.ke/news/article-157910/6000-lamu-squatters-want-their-land-back).

${ }^{81}$ See Galgalo Bocha and Kalume Kazungu, "Offices, vehicle burnt as gang attacks Amu Ranch in Lamu", The East African, July 8, 2014 (http://www.theeastafrican.co.ke/news/Offices-vehicle-burnt-as-gang-attacks-ranchin-Lamu/-/2558/2376186/-/84ieiu/-/index.html).

${ }^{82}$ Korf et al. "Respacing the African Drylands".

${ }^{83}$ Elliott, "Planning".

${ }^{84}$ Greiner, "Land-use changes".

${ }^{85}$ Cormack, "Pastoralist heritage".

${ }^{86}$ Schlee and Shongolo, Pastoralism and politics; Watson, "Hardening of lines".

87 Blomley, "Law, Property".

${ }^{88}$ Scott, Seeing Like a State, 7.

${ }^{89}$ McIlwaine, "Civil Society".

${ }^{90}$ Scott, Seeing Like a State, 49.

${ }^{91}$ Sharp et al., "Entanglements of Power".

92 https://www.savelamu.org (Accessed 24 March 2016).

${ }^{93} \mathrm{http}: / / \mathrm{www}$.friendsoflaketurkana.org (Accessed 24 March 2016).

${ }^{94} \mathrm{http}$ ://siplf.org/en/Home/ (Accessed 24 March 2016).

${ }^{95}$ Cormack, "Pastoralist heritage". 
96 Patey, "Oil Upstart".

${ }^{97}$ Cormack, "Pastoralist heritage".

${ }^{98}$ Hall et al. Powers of Exclusion, 171.

${ }^{99}$ Daily Nation http://www.nation.co.ke/counties/Lapsset-surveyors-Isiolo/-/1107872/2960044/-/qcl210z/lindex.html (accessed 5 April 2016); Cormack, "Pastoralist heritage".

100 Blomley, "Law, Property"

101 Greiner, "Land-use change".

102 Buffavand, "The land".

103 Adams, Wasting the Rain.

${ }^{104}$ Oxford English Dictionary.

105 Oxford English Dictionary

\section{References}

Abbink, Jon. "'Land to the foreigners': economic, legal, and socio-cultural aspects of new land acquisition schemes in Ethiopia". Journal of Contemporary African Studies, Vol. 29, Iss. 4 (2011): 513-535. DOI: 10.1080/02589001.2011.603213

Adams, William M. Against extinction: the story of conservation. Earthscan, 2013.

Adams, William M. Wasting the Rain (Routledge Revivals): Rivers, People and Planning in Africa. Routledge, 2014.

Anderson, David and Jacob McKnight, 'Kenya at war: Al-Shabaab and its enemies In Eastern Africa', African Affairs, (2015) 114 (454): 1-27. DOI: 10.1093/afraf/adu082.

Anderson, David. Why Mpeketoni matters: al-Shabaab and violence in Kenya, NOREF Policy Brief, September 2014.

Asnake Kefale and Fana Gebresenbet, "Expansion of the Sugar Industry in the Southern Pastoral Lowlands". Chapter 9 In Rahmato et al (eds). Reflections on Development in Ethiopia: New Trends, Sustainability and Challenges. Addis Ababa: Forum for Social Studies/Fredrich Ebert Stiftung. 2014.

Avery, Sean. The impacts of hydropower and irrigation development on the world's largest desert lake: what future Lake Turkana?, Oxford: African Studies Centre, University of Oxford, 2013.

Bach, Jean-Nicolas. "Abyotawi democracy: neither revolutionary nor democratic, a critical review of EPRDF's conception of revolutionary democracy in post-1991 Ethiopia". Journal of Eastern African Studies, 5, no. 4 (2011): 641-663.

Barber, J. Imperial frontier. Nairobi: East African Publishing House. 1968.

Blomley, Nicholas. "Law, property, and the geography of violence: The frontier, the survey, and the grid." Annals of the Association of American Geographers 93, no. 1 (2003): 121-141.

Bridge, Gavin. "Resource geographies II The resource-state nexus." Progress in Human Geography (2013): 0309132513493379.

Browne, Adrian J. "LAPSSET: The history and politics of an eastern African megaproject". London: Rift Valley Institute. 2015 (http://riftvalley.net/download/file/fid/3897).

Buffavand, Lucie. “"The land does not like them": contesting dispossession in cosmological terms in Mela, South-West Ethiopia”. Journal of Eastern African Studies, 10(3), 2016.

Carmody, Padraig. "An Asian-driven economic recovery in Africa? The Zambian case." World Development 37, no. 7 (2009): 1197-1207.

Catley, Andy, Jeremy Lind and Ian Scoones, eds. Pastoralism and Development in Africa: Dynamic Change at the Margins. London: Routledge. 2013. 
Chome, Ngala. "“Devolution is only for development'? Decentralization and elite vulnerability on the Kenyan coast". Critical African Studies, Vol. 7, Iss. 3, 2015. DOI: $10.1080 / 21681392.2015 .1075750$

Clapham, Christopher. Transformation and Continuity in Revolutionary Ethiopia. Cambridge: Cambridge University Press. 1988.

Cormack, Zoe. "The promotion of pastoralist heritage and alternative 'Visions' for the future of northern Kenya". Journal of Eastern African Studies, 10(3), 2016.

Cross, Jamie. Dream Zones: Anticipating Capitalism and Development in India. Pluto Press, 2014.

Dereje Feyissa and Markus Hoehne (eds). Borders and Borderlands as Resources in the Horn of Africa. Woodbridge: James Currey. 2010.

Dereje Feyissa. 'Aid negotiation: the uneasy "partnership" between EPRDF and the donors'. Journal of Eastern African Studies, 5, no. 4 (2011): 788-817.

Dodds, Klaus. "1.1 The Third World, developing countries, the South, poor countries." The companion to development studies (2008): 3.

Donham, Donald and Wendy James (eds). The Southern Marches of Imperial Ethiopia. Oxford: James Currey. 1986.

Elliott, Hannah. "Planning, property and plots at the gateway to Kenya's 'new frontier"'. Journal of Eastern African Studies, 10(3), 2016.

Enns, Charis. "The master's tools: Voluntary social and environmental standards and the politics of legitimacy in Kenya's extractive sector". Initiatives in Critical Agrarian Studies The Hague: ISS. 2016.

Eshetu Chole. Underdevelopment in Ethiopia. Addis Ababa: Organization for Social Science Research in Eastern and Southern Africa (OSSREA). 2004.

Federal Democratic Republic of Ethiopia (FDRE). The Second Growth and Transformation Plan. 2015.

Ferguson, James. "Seeing like an oil company: space, security, and global capital in neoliberal Africa." American anthropologist 107, no. 3 (2005): 377-382.

Fourie, E., 2015. "China's example for Meles' Ethiopia: when development 'models' land". The Journal of Modern African Studies, 53(03): 289-316.

Fratkin, Elliot. "Ethiopia's Pastoralist Policies: Development, Displacement and Resettlement". Nomadic Peoples, Volume 18, Number 1, 2014, pp. 94-114(21).

Gilman, Nils. Mandarins of the Future: Modernization Theory in Cold War America. London: JHU Press. 2007.

Government of Kenya. Vision 2030 Development Strategy for Northern Kenya and other Arid Lands. March 2012.

Greiner, Clemens. "Unexpected consequences: Wildlife conservation and territorial conflict in Northern Kenya." Human Ecology 40, no. 3 (2012): 415-425.

Greiner, Clemens. "Land-use change, territorial restructuring, and economies of anticipation in dryland Kenya". Journal of Eastern African Studies, 10(3), 2016.

Hall, Derek, Philip Hirsch, and Tania Murray Li. Powers of Exclusion: Land Dilemmas in Southeast Asia. University of Hawai'i Press. 2011.

Hutton, Jon, William M. Adams, and James C. Murombedzi. "Back to the barriers? Changing narratives in biodiversity conservation." In Forum for development studies, vol. 32, no. 2, pp. 341-370. Taylor \& Francis Group, 2005.

James, Wendy, Donald Donham, Eisei Kurimoto and Alessandro Triulzi (eds). Remapping Ethiopia: Socialism and After. Oxford: James Currey. 2002.

Kabukuru, Wanjohi. 'Why Kenya Is Fighting In Somalia', New African Magazine, April 1, 2012 (http://newafricanmagazine.com/why-kenya-is-fighting-insomalia/\#sthash.2mcp1j6V.dpuf) 
Kamski, Benedikt. "The Kuraz Sugar Development Project (KSDP) in Ethiopia: between 'sweet visions' and mounting challenges". Journal of Eastern African Studies, 10(3), 2016

Kimenyi, Mwangi S. 'Devolution and Resource Sharing in Kenya'. Brookings Institute. October 22, 2013. (http://www.brookings.edu/research/opinions/2013/10/22devolution-resource-sharing-kenya-kimenyi)

Kochore, Hassan H.. "The road to Kenya? Visions, expectations and anxieties around new infrastructure development in Northern Kenya". Journal of Eastern African Studies, 10(3), 2016.

Korf, Benedikt, Tobias Hagmann \& Rony Emmenegger. "Re-spacing African drylands: territorialization, sedentarization and indigenous commodification in the Ethiopian pastoral frontier". The Journal of Peasant Studies, Vol. 42, Iss. 5 (2015). DOI: 10.1080/03066150.2015.1006628

Lavers, Tom. "Patterns of agrarian transformation in Ethiopia: State mediated commercialisation and the 'land grab'". The Journal of Peasant Studies, 39:3-4, (2012): 795-822. DOI: 10.1080/03066150.2012.660147

Lefort, Rene. 'The Ethiopian Economy: the Developmental State vs the Free Market'. Chapter 14, Prunier, Gerard and Eloi Ficquet (eds), Understanding Contemporary Ethiopia: Monarchy, Revolution and the Legacy of Meles Zenawi. London: Hurst. 357-394. 2015.

Li, Tania Murray. "Beyond "the state" and failed schemes." American anthropologist 107, no. 3 (2005): 383-394.

Linehan, Denis. "Re-ordering the Urban Archipelago: Kenya Vision 2030, Street Trade and the Battle for Nairobi City Centre". Aurora Geography Journal, 1, (2007): 21-37.

Makki, Fouad. "Development by Dispossession: Terra Nullius and the Social - Ecology of New Enclosures in Ethiopia." Rural Sociology 79, no. 1 (2014): 79-103.

Markakis, John. Ethiopia: The Last Two Frontiers. Oxford: James Currey. 2011.

Mawdsley, Emma. "Development geography 1 Cooperation, competition and convergence between 'North'and 'South'." Progress in Human Geography (2015): 0309132515601776.

Mawdsley, Emma. "DFID, the private sector and the re-centring of an economic growth agenda in International development." Global Society 29, no. 3 (2015): 339-358.

McIlwaine, Cathy. "Civil society and development geography". Progress in Human Geography. June 1998, 22: 415-424, DOI:10.1191/030913298669927952

Menkhaus, Ken. "Conflict Assessment/2014: Northern Kenya and Somaliland”. Final, corrected version. Danish Demining Group. March 2015. (http://danishdemininggroup.dk/media/1562973/conflict-assesment-northern-kenyaand-somaliland-final-180315-mid-res-.pdf)

Mitchell, Timothy. Rule of experts: Egypt, techno-politics, modernity. Univ of California Press, 2002.

Mohan, Giles. "Beyond the enclave: towards a critical political economy of China and Africa." Development and Change 44, no. 6 (2013): 1255-1272.

Mosley, Jason. (2012). "Peace, bread and land: Agricultural investments in Ethiopia and the Sudans". Africa Programme Briefing Paper (London: Chatham House), http://www.chathamhouse.org/publications/papers/view/181519.

Oba, Gufu. Nomads in the Shadows of Empires: Contests, Conflicts and Legacies on the Southern Ethiopian-Northern Kenyan Frontier. Leiden: Brill. 2013.

Okumu, Wafula. "Resources and border disputes in Eastern Africa". Journal of Eastern African Studies. 4, No. 2 (2010). 
Otieno, Fred. 'Kenya: Devolution and prospects for peace'. Horn of Africa Bulletin. Life \& Peace Institute. December 16, 2014. (http://life-peace.org/hab/devolution-andprospects-for-peace/)

Patey, Luke. "Kenya: An African oil upstart in transition". Oxford Institute for Energy Studies, OIES PAPER: WPM 53. 2014. (https://www.oxfordenergy.org/wpcms/wpcontent/uploads/2014/10/WPM-53.pdf)

Power, Marcus. "Angola 2025: The Future of the "World's Richest Poor Country" as Seen through a Chinese Rear - View Mirror." Antipode 44, no. 3 (2012): 993-1014. Reid, Richard. Frontiers of Violence in North-East Africa: Genealogies of Conflict since 1800. Oxford: Oxford University Press. 2011.

Rosen, Jon. 'Strategic Posture Review: Kenya'. World Politics Review, January 21, 2014 (http://www.worldpoliticsreview.com/articles/13509/strategic-posture-review-kenya).

Schlee, Günther and Abdullahi A. Shongolo. Pastoralism and Politics in Northern Kenya and Southern Ethiopia. Oxford: James Currey. 2012.

Schlee, Günther and Elizabeth E. Watson, eds. Changing Identifications and Alliances in North-east Africa. Volume I: Ethiopia and Kenya. Oxford: Berghahn. 2009.

Scott, James. Seeing Like a State: How Certain Schemes to Improve the Human Condition Have Failed. Yale University Press: London. 1998.

Sharp, Joanne P., Paul Routledge, Chris Philo and Ronan Paddison, eds. Entanglements of Power: Geographies of domination/resistance. London: Routledge. 2000.

Think Security Press, A National Security Profile on the Republic of Kenya, August 2014 (http://thinksecurityafrica.org/wordpress/wp-content/uploads/National-SecurityProfile-Kenya.pdf).

Totolo, Edoardo. Kenya's 'Economic' Conflict with Al-Shabaab, ISN Blog, June 5, 2012 (http://www.isn.ethz.ch/Digital-Library/Articles/SpecialFeature/Detail/?id=143305\&contextid774=143305\&contextid775=143303\&tabid=14 52421382)

Turton, David. "Wilderness, wasteland or home?" Journal of Eastern African Studies. 5, no. 1 (2011): 158-176.

Vaughan, Sarah. "Revolutionary democratic state-building: party, state and people in the EPRDF's Ethiopia”. Journal of Eastern African Studies, 5, no. 4 (2011): 619-640.

Watson, Elizabeth E. "A "hardening of lines": landscape, religion and identity in northern Kenya”. Journal of Eastern African Studies, 4, no. 2 (2010): 201-220. DOI: 10.1080/17531055.2010.487330

Whittaker, Hannah. Insurgency and Counterinsurgency in Kenya: A Social History of the Shifta Conflict, c. 1963-1968. Leiden: Brill. 2015. 